\title{
Upflow Anaerobic Filter for the Treatment of Wastewater from a Natural Rubber Latex Concentration Unit
}

\author{
Nithya Gopinath*, Madhu G.*† and Joseph Francis** \\ *Division of Chemical Engineering and Division of Safety and Fire Engineering, School of Engineering, Cochin University \\ of Science and Technology, Cochin-682 022, India \\ **Oman Medical College, National University of Science and Technology, Muscat, Sultanate of Oman \\ †Corresponding author: Madhu G.; profmadhugopal@gmail.com
}

Nat. Env. \& Poll. Tech.

Website: www.neptjournal.com

Received: $14-10-2020$

Revised: 15-02-2021

Accepted: 22-02-2021

Key Words:

Upflow anaerobic filter

Rubber latex wastewater

Volatile acids

Methane

\begin{abstract}
In this study, wastewater from a centrifuge rubber latex concentration unit was experimentally treated by an up-flow anaerobic filter (UAF) at variable hydraulic detention time to investigate the COD removal efficiency and the gas production rate. The UAF reactors were made of PVC pipe with an inside diameter of $9.5 \mathrm{~cm}, 180 \mathrm{~cm}$ in height, with a bed volume of $12.8 \mathrm{~L}$, and filled with polyethylene media. The initial COD concentration of wastewater was in the range $4620-10400 \mathrm{mg} . \mathrm{L}^{-1}$. HRTs were controlled at 20 days, with the organic loading rate varying from 2.9 to $10.5 \mathrm{~kg}$.day. $\mathrm{m}^{-3}$. The findings show that the COD removal efficiency of the system was in the range of $85 \%$ to $92 \%$ for the varying organic loading rates. In addition, the specific methane production rate varied from 8.2 to $14 \mathrm{~L}$ of $\mathrm{CH}_{4}$ produced/g of COD destroyed/day for the different organic loading rates.
\end{abstract}

\section{INTRODUCTION}

Anaerobic biological treatment of high-strength organic wastes has a number of advantages which makes it preferable to either aerobic biological or physical-chemical treatment methods. The major advantage is that a high degree of waste stabilization can be accomplished with relatively low production of biological solids thus reducing the costs associated with sludge disposal. Methane gas is produced as a result of the anaerobic process and valuable energy can be recovered from the gas by subsequent combustion.

A disadvantage of the anaerobic process is the low bacterial growth rate which may result in a washout of the biomass if the solids in the effluent are not returned to the unit. Young \& Mc Carty (1969) therefore developed an up-flow anaerobic filter in which the anaerobic bacteria are present in a film attached to a rock medium to remove organics in the waste flowing upward through the column. The bacteria in the anaerobic filter are firmly attached to the medium resulting in a sludge age of more than 150 days (Behera et al. 2007). The unit can therefore be operated at temperatures substantially below $35^{\circ} \mathrm{C}$ which decreases the bacterial growth rate while still maintaining sufficient biomass.

The studies carried out by Young \& Mc Carty (1969) using synthetic organic waste indicated that at the same organic loading the percentage of COD removal increased when the concentration of the influent COD increased. The unit consisted of a group of six filters operating in series. Their study based on synthetic wastewater indicated that the percentage removal of organic material is constant regardless of the concentration of the organic load applied to anaerobic filters in a continuous flow system.

Acharya et al. (2008) studied the suitability of an anaerobic filter for the treatment of distillery spent wash. The results of the study showed that up to a certain organic loading, the increase in BOD and COD of the effluent is accompanied by an increase in the percentage removal of COD and BOD, where after the decline in percentage removal with increased organic loading is exponential. A study carried out by Omil et al. (2003) investigated the performance of an anaerobic filter for the treatment of complex dairy wastewater on an industrial scale. During the last three decades, several studies (Tritt 1992, Manariotis \& Grigoropoulis 2006, Iscen et al. 2007, Delpozo et al. 2000, Rajakumar et al. 2011, Burcu et al. 2016) have been carried out to evaluate the performance of anaerobic filters for the treatment of wastewaters from various types of industries. The anaerobic filter has also been applied successfully as a reactor for the biological denitrification of effluents (Tilche et al. 1994, Hanne \& Birgitte 1996, Bodik et al. 2003).

Among the various methods of natural rubber latex processing, the wastewaters from centrifuge latex concentration 
units have been found to have the highest pollution potential (Madhu et al. 1994). The purpose of the present study is to evaluate the performance of an upflow anaerobic filter for the treatment of wastewaters from a centrifuge rubber latex concentration unit.

\section{MATERIALS AND METHODS}

A bench-scale anaerobic contact filter was fabricated using a PVC pipe of $9.5 \mathrm{~cm}$ diameter and $180 \mathrm{~cm}$ height having a total volume of $0.012 \mathrm{~m}^{3}(12 \mathrm{~L})$. A length of $7 \mathrm{~cm}$ was leftover for sedimentation and distribution of wastewater at the bottom of the column. Sampling ports were provided at every $30 \mathrm{~cm}$ height of the filter from the perforated plate up to $150 \mathrm{~cm}$. The reactor was filled with polyethylene media with a surface area of $240 \mathrm{~m}^{2} \cdot \mathrm{m}^{-3}$, void $90 \%$, specific gravity 0.95 , and standard size $40 \mathrm{~mm}$. A clear liquid column of 30 $\mathrm{cm}$ was provided above the media for the separation of the effluent, suspended solids, and gas. A space of $13 \mathrm{~cm}$ has been provided for the accumulation of gas produced. The gas was collected by the displacement method. The filter was fed with wastewater at the point just below the perforated support plate from a storage vessel by means of a peristaltic pump. A schematic diagram of the experimental setup is shown in Fig. 1.
Active biomass was grown on the surface of the filter media by daily feeding a mixture of sewage and cow dung slurry $(1 \%)$ into the filter. Significant growth of bacteria was observed as evident from the methane gas production after 20 days of continuous operation. Four composite wastewater samples were collected from a centrifuge rubber latex concentration unit and brought to the laboratory with proper preservation. For proper acclimatization, the proportion of sewage was reduced to $90 \%, 80 \%, 70 \%$, etc., by adding increasing quantities of the rubber latex centrifuging effluent. After 15 days of this continuous acclimatization, a steady state was achieved for a COD concentration of 9500 $\mathrm{mg} . \mathrm{L}^{-1}$. The $\mathrm{pH}$ of the feed solution was adjusted to 6.4 by adding sodium carbonate and the solution was fed into the filter at different hydraulic loadings $(7.20,8.64,10.08$, and 11.52 L.day ${ }^{-1}$ ).

The following parameters were monitored during the course of the experiments which lasted for 15 days.

a. Measurement of $\mathrm{pH}$ and alkalinity of the influent and effluent every day.

b. Estimation of COD, BOD, and volatile acids content of the effluent daily using standard methods (APHA, AWWA \& WPCF 1995).

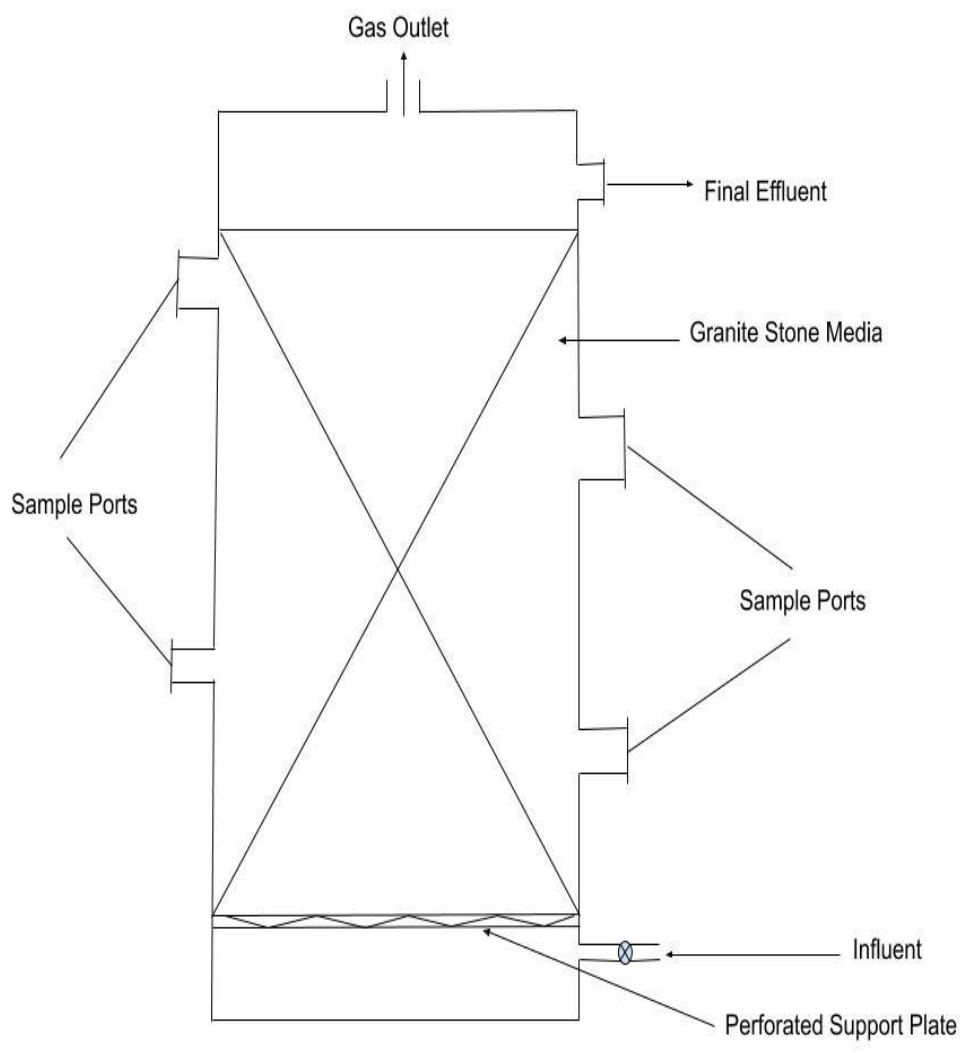

Fig. 1: Experimental set-up for upflow anaerobic filter. 
c. Analysis of the biogas produced for its methane content at the end of 15 days of steady-state operation of the filter using a gas chromatograph.

The above procedure was repeated for other influent COD concentrations of $10400 \mathrm{mg} . \mathrm{L}^{-1}, 5800 \mathrm{mg} . \mathrm{L}^{-1}$, and 4620 $\mathrm{mg} . \mathrm{L}^{-1}$. Adequate time was provided for acclimatization between changes of organic as well as hydraulic loadings.

\section{RESULTS AND DISCUSSION}

The characteristics of the wastewater samples used in the study are given in Table 1 . The waste analysis indicated that the waste was nutrient-limited by phosphorous. For an unhindered anaerobic treatment of waste at full strength, at least $800 \mathrm{mg} . \mathrm{L}^{-1}$ of nitrogen and $160 \mathrm{mg} . \mathrm{L}^{-1}$ of phosphorous would be needed (Bodik et al. 2002). To maintain unhindered anaerobic growth, phosphorous in the form of dibasic potassium phosphate was added to the feed wastewater in sufficient quantities to maintain a phosphorous: nitrogen: carbon ratio of 1: 5.9: 100. The addition of potassium phosphate served two purposes. It not only provided the required phosphorous, but it increased the buffer capacity of the system to a limited extent. During periods of decreased alkalinity, the amount of potassium phosphate added to the feed was increased to provide additional buffer capacity.

\section{pH Value}

pH range of 6.4 to 7.3 was observed for various organic loading rates of latex concentration effluent. The $\mathrm{pH}$ variation observed for the organic loading rates, 6 kg.day. $\mathrm{m}^{-3}$ and 7.2 $\mathrm{kg}$.day. $\mathrm{m}^{-3}$ are plotted in Fig. 2. In all the loading conditions, reduction in $\mathrm{pH}$ was observed in one-day detention samples

Table 1: Characteristics of the wastewater samples used for the study.

\begin{tabular}{|lllll|}
\hline Parameter & Sample 1 & Sample 2 & Sample 3 & Sample 4 \\
\hline $\mathrm{pH}$ & 4.2 & 4.0 & 4.0 & 3.9 \\
Total Solids [mg. $\left.\mathrm{L}^{-1}\right]$ & 8200 & 17280 & 12875 & 8800 \\
Dissolved Solids $\left[\mathrm{mg} . \mathrm{L}^{-1}\right]$ & 6300 & 11140 & 10800 & 8010 \\
Suspended Solids $\left[\mathrm{mg} . \mathrm{L}^{-1}\right]$ & 1900 & 6140 & 2075 & 790 \\
COD $\left[\mathrm{mg} . \mathrm{L}^{-1}\right]$ & 9500 & 10400 & 5800 & 4620 \\
BOD [mg. $\left.\mathrm{L}^{-1}\right]$ & 5700 & 6100 & 3100 & 2800 \\
Total Kjeldahl Nitrogen $\left[\mathrm{mg} . \mathrm{L}^{-1}\right]$ & 1500 & 1880 & 1580 & 1560 \\
Ammoniacal Nitrogen $\left[\mathrm{mg} . \mathrm{L}^{-1}\right]$ & 630 & 750 & 590 & 710 \\
\hline
\end{tabular}

pH vs Days of Operation

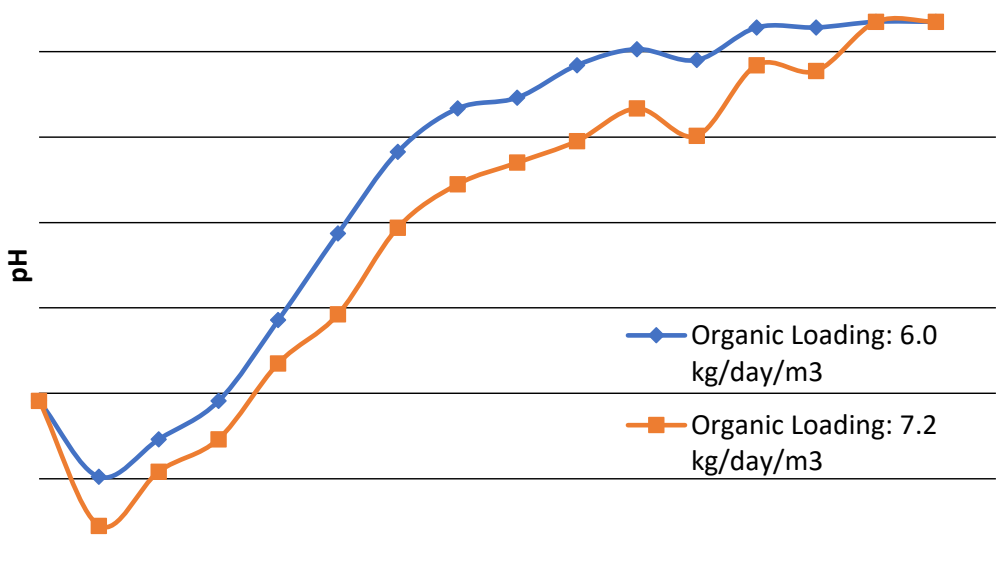

Days of Operation

Fig. 2: Variation of $\mathrm{pH}$ during the operation of UAF for different organic loading rates. 
because of the production of volatile acids but subsequently, it remained neutral because of the conversion of volatile acids to biogas (Kobayashi et al. 1983).

\section{Variation in Alkalinity}

The variation in alkalinity experienced in the filter during the experimental run of 15 days is shown in Fig. 3. The alkalinity values were measured for the two organic loadings, viz., 6 kg.day. $\mathrm{m}^{-3}$ and $7.2 \mathrm{~kg}$.day. $\mathrm{m}^{-3}$, show that the fluctuations occurring have been taken care of by the bacterial mass in the filter. There is practically no difference between the initial and final alkalinity values which indicates a steady-state operation of the filter.

\section{COD Removal}

Steady-state COD removal efficiency was obtained after a period of operation at a given loading. The results of a series of organic loading changes are illustrated in Fig. 4.

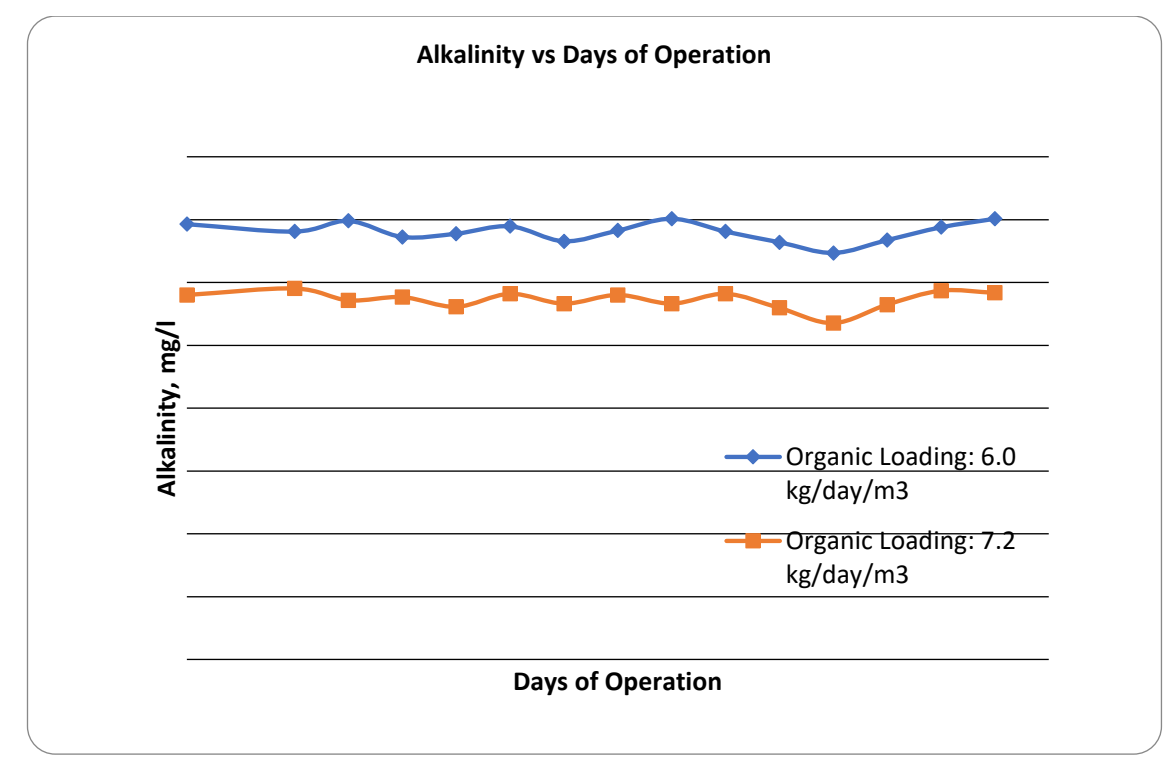

Fig. 3: Variation in alkalinity during the experimental run.

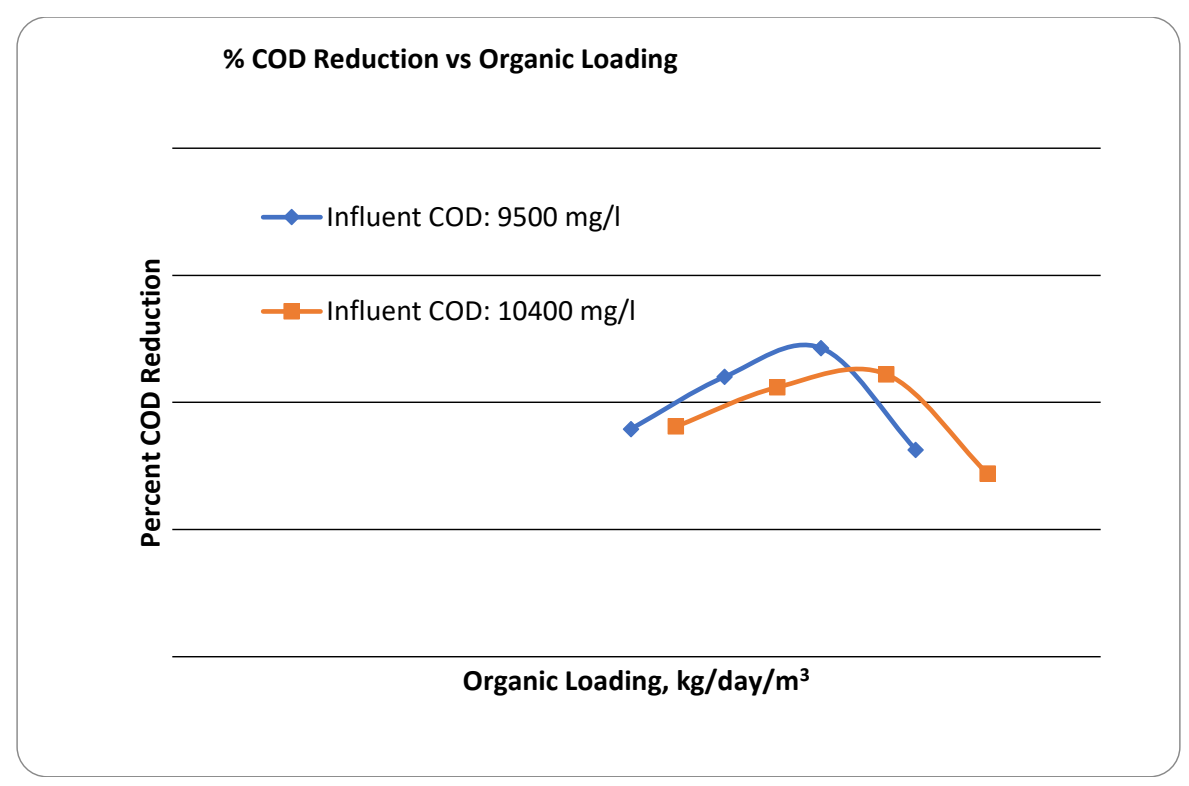

Fig. 4: COD removal efficiency for various organic loadings. 
Initially, latex effluent with a COD of $9500 \mathrm{mg} . \mathrm{L}^{-1}$ was fed to the filter at a loading rate of $6 \mathrm{~kg}$.COD.day. $\mathrm{m}^{-3}$. This was followed by loading rates of $7.2,8.4$, and $9.6 \mathrm{~kg}$.day. $\mathrm{m}^{-3}$. On increasing the loading rate from 6 to 8.4 , the COD removal efficiency increased from 89 percent to 92 percent. But when the loading rate was further increased to $9.6 \mathrm{~kg}$.day. $\mathrm{m}^{-3}$, the COD removal dropped to 88 percent. The same trend was observed at an influent COD concentration of $10400 \mathrm{mg} . \mathrm{L}^{-}$ 1. Although the COD removal efficiency increased from 89 percent to 91 percent, on increasing the organic loading rate from $6.57 \mathrm{~kg}$.day. $\mathrm{m}^{-3}$ to $9.19 \mathrm{~kg}$.day. $\mathrm{m}^{-3}$, it dropped to 87 percent on further increasing the loading rate to $10.5 \mathrm{~kg}$.day. $\mathrm{m}^{-3}$.

It is seen that the COD removal efficiencies decrease with an increase in organic loadings beyond a particular limit. This may be due to substrate inhibition, or inadequate acclimatization of bacteria, or formation of propionic acids (Ioannis et al. 2006).

The percentage COD reduction obtained on each day of operation of the filter is shown in Fig. 5. The curves plotted for different organic loading rates show that rapid COD removals are obtained in the first-day detention samples. This should be due to the active biomass present on the filter medium which decomposes the organic matter in the feed wastewater very efficiently (Sharma et al. 2014). For all the loading rates, most of the COD removal was found to take place during the first 10 days of operation. This summarizes the fact that most of the stabilization of the waste should be occurring during the first ten days of operation. The COD removal efficiencies achieved for different influent concentrations are summarized in Table 2.

\section{BOD Removal}

As in the case of COD removal, the BOD removal efficiency also increased with organic loading up to a certain limit. The variation of BOD removal with organic loading is illustrated in Fig. 6. When the organic loading rate was increased from $6 \mathrm{~kg}$.day. $\mathrm{m}^{-3}$ to $8.4 \mathrm{~kg}$.day. $\mathrm{m}^{-3}$ for an influent COD of $9500 \mathrm{mg} . \mathrm{L}^{-1}$, the BOD removal efficiency increased from 92.5 percent to 96.0 percent. But on increasing the organic loading rate to $9.6 \mathrm{~kg}$.day. $\mathrm{m}^{-3}$, the BOD removal efficiency was found to drop to 91.0 percent. The same pattern was repeated for other influent COD concentrations also. The reason for this behavior should be substrate inhibition or improper acclimatization of bacterial mass.

The variation of BOD with detention time is shown in Fig 7. Rapid BOD removals were observed in the first-day detention samples in all the loading conditions which confirm the presence of active biomass in the filter. The BOD removal efficiencies achieved during the course of the experiments are given in Table 2.

\% COD Reduction vs Days of Operation

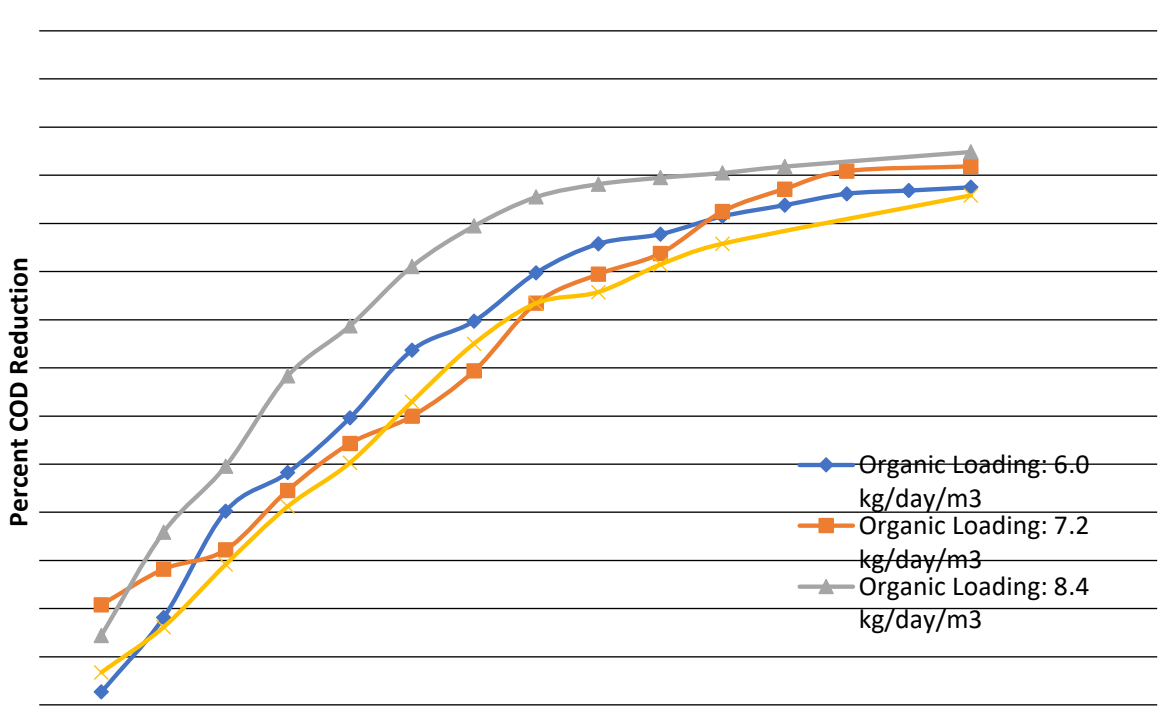

Days of Operation

Fig. 5: COD reduction on a daily basis during the operation of the UAF. 
Table 2: BOD and COD removal efficiency for different influent concentrations.

\begin{tabular}{|c|c|c|c|}
\hline Influent COD Concentration $\left[\mathrm{mg} . \mathrm{L}^{-1}\right]$ & Organic Loading Rate $\left[\mathrm{kg}\right.$.day. $\left.\mathrm{m}^{-3}\right]$ & Percent COD Removal & Percent BOD Removal \\
\hline \multirow[t]{4}{*}{9500} & 6.0 & 89.0 & 92.5 \\
\hline & 7.2 & 91.0 & 94.0 \\
\hline & 8.4 & 92.0 & 95.0 \\
\hline & 9.6 & 88.0 & 91.0 \\
\hline \multirow[t]{4}{*}{10400} & 6.57 & 89.0 & 91.0 \\
\hline & 7.88 & 90.5 & 93.0 \\
\hline & 9.19 & 91.0 & 94.0 \\
\hline & 10.50 & 87.0 & 90.0 \\
\hline \multirow[t]{4}{*}{5800} & 3.66 & 87.0 & 90.5 \\
\hline & 4.39 & 88.0 & 91.5 \\
\hline & 5.13 & 89.0 & 93.0 \\
\hline & 5.86 & 86.0 & 88.5 \\
\hline \multirow[t]{4}{*}{4620} & 2.92 & 87.0 & 90.0 \\
\hline & 3.50 & 89.0 & 91.0 \\
\hline & 4.08 & 90.5 & 94.0 \\
\hline & 4.67 & 85.0 & 90.0 \\
\hline
\end{tabular}

\section{Volatile Acids}

The volatile acid concentration of the effluent during the period of operation of the filter is shown in Fig. 8. For all the organic loading rates, there was a steep increase in the production of volatile acids during the initial period. This should be due to the increased activity of non-methanogenic bacteria which produce volatile acids (Zabihollah et al. 2018). But as the detention time increased, the volatile acid concentration came down. The conversion of volatile acids to methane by bio-methanation should have caused the drop in volatile acids concentration.

\section{Biogas Production}

Biogas production is the final step of the anaerobic process and is due to the conversion of volatile acids to gaseous form by methanogenic bacteria. The volume of gas generated

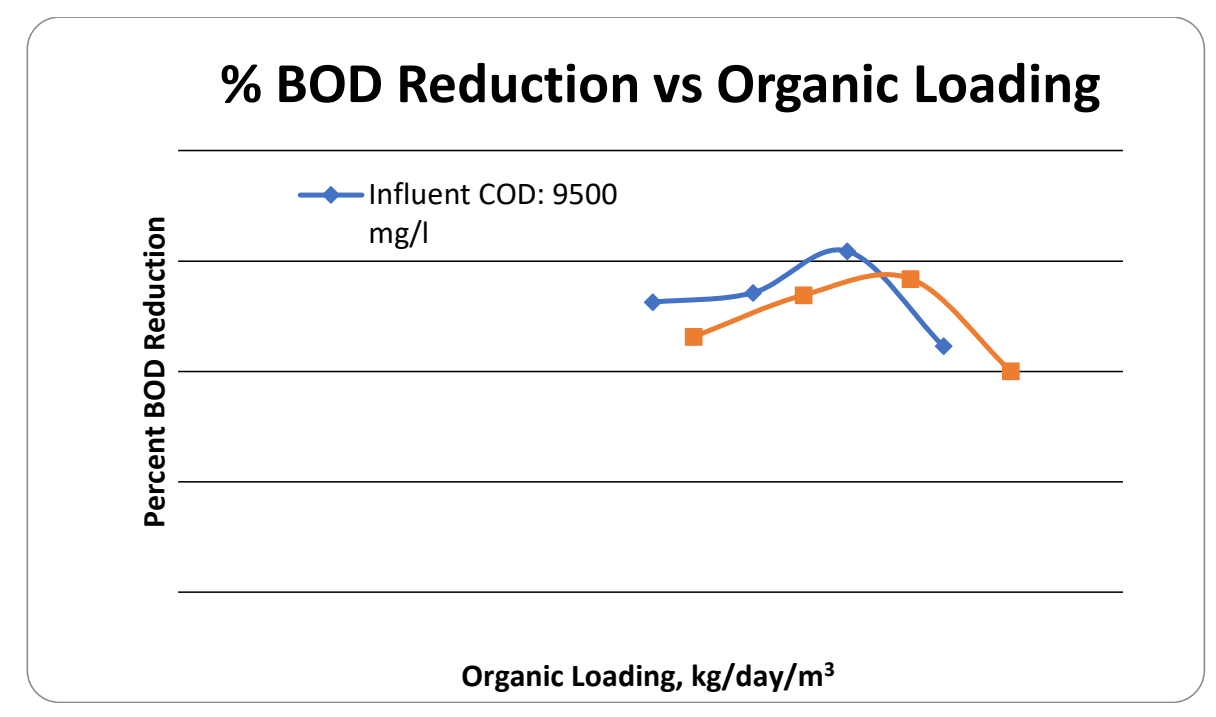

Fig. 6: The variation of BOD removal efficiency with organic loading. 


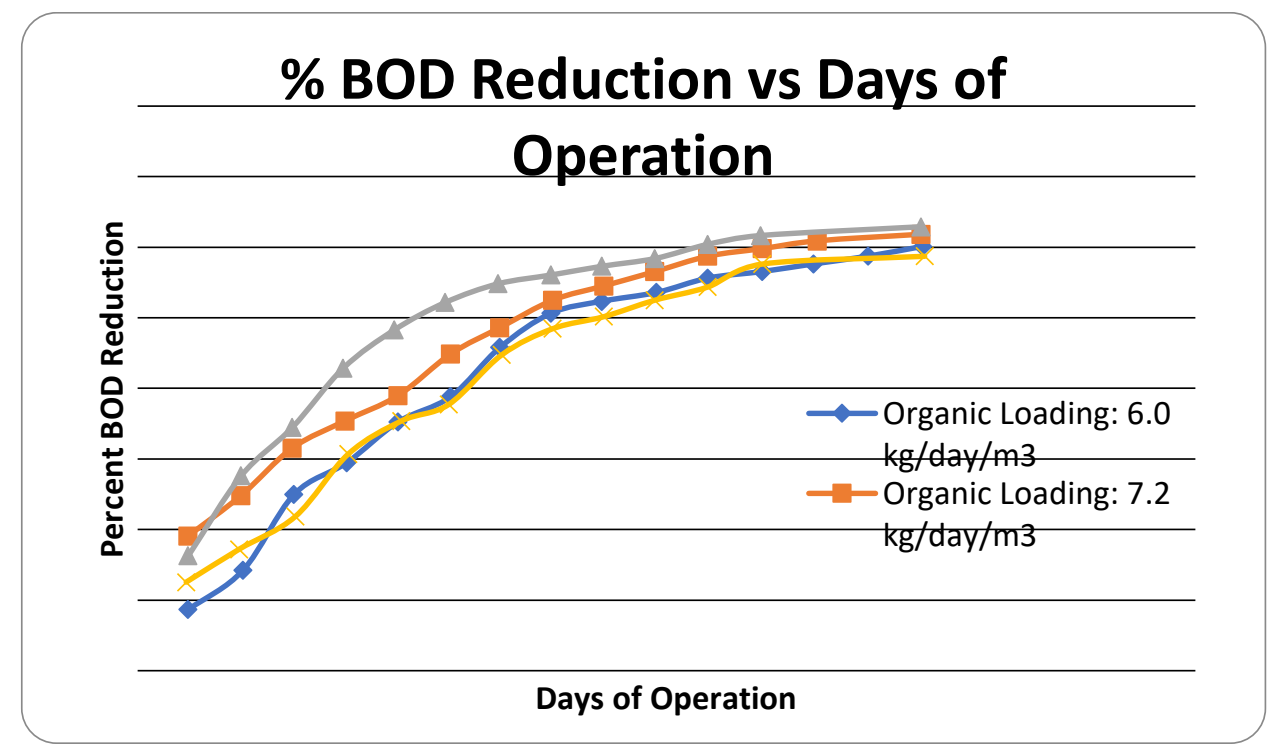

Fig. 7: Variation of BOD with detention time.

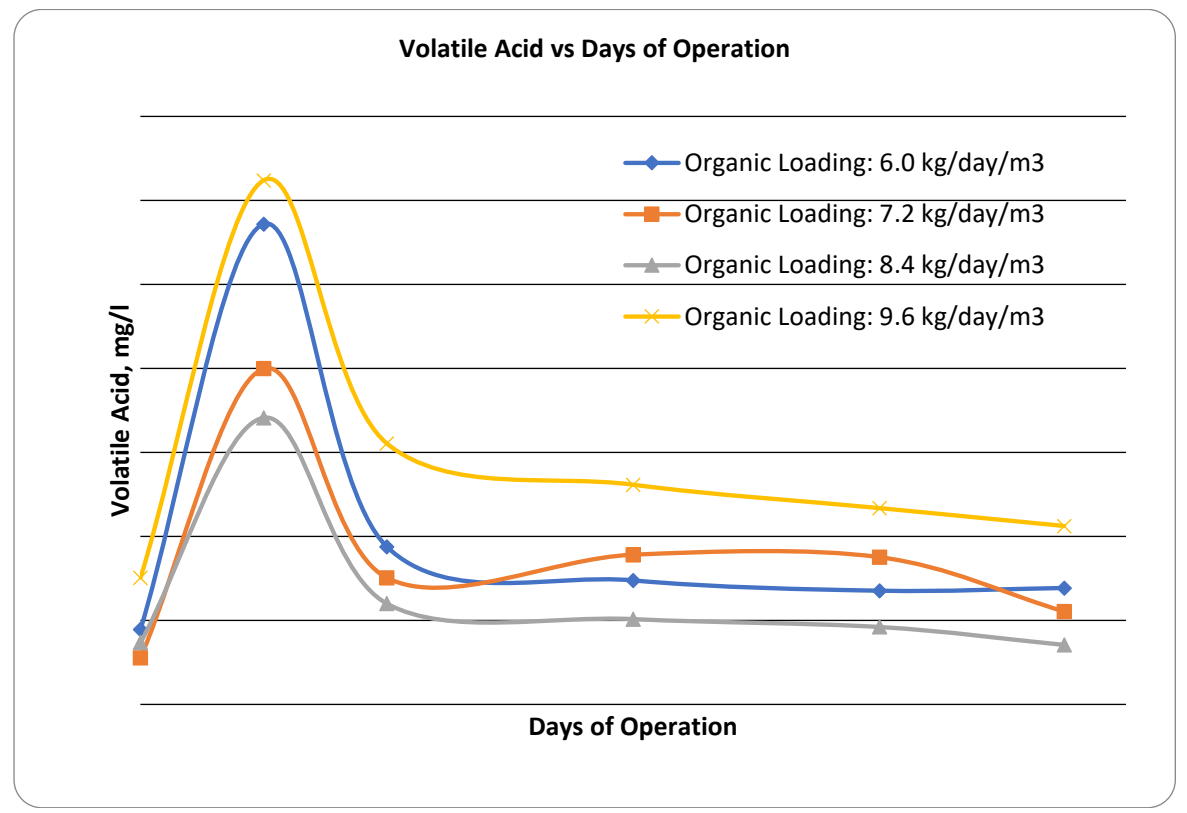

Fig. 8: The volatile acid concentration of the effluent during the period of operation of the filter.

and its methane content for different organic loadings are plotted in Fig. 9.

For an influent COD concentration of $9500 \mathrm{mg} . \mathrm{L}^{-1}$, the volume of gas collected during 15 days of operation of the filter was $1350 \mathrm{~L}$, i.e., $90 \mathrm{~L}$ of gas production per day on an average at an organic loading rate of $6.0 \mathrm{~kg}$.day. $\mathrm{m}^{-3}$. The volume of gas collected rose to $1600 \mathrm{~L}\left(107 \mathrm{~L} . d a y^{-1}\right)$ on increasing the organic loading rate to $8.4 \mathrm{~kg}$.day. $\mathrm{m}^{-3}$. But on increasing the organic loading rate further to $9.6 \mathrm{~kg} \cdot$ day. $\mathrm{m}^{-3}$, the volume of biogas produced was found to decrease to $1475 \mathrm{~L}$. The same trend was observed for an influent COD concentration of $10400 \mathrm{mg} . \mathrm{L}^{-1}$. On increasing the organic loading rate from $6.57 \mathrm{~kg}$.day. $\mathrm{m}^{-3}$ to $9.19 \mathrm{~kg}$.day. $\mathrm{m}^{-33}$, the gas production increased from $1425 \mathrm{~L}$ to $1750 \mathrm{~L}$. While increasing the organic loading rate to $10.5 \mathrm{~kg}$.day. $\mathrm{m}^{-33}$, the volume of gas dropped to $1520 \mathrm{~L}$.

The methane content of the biogas produced also varied with organic loading. As in the case of gas pro- 


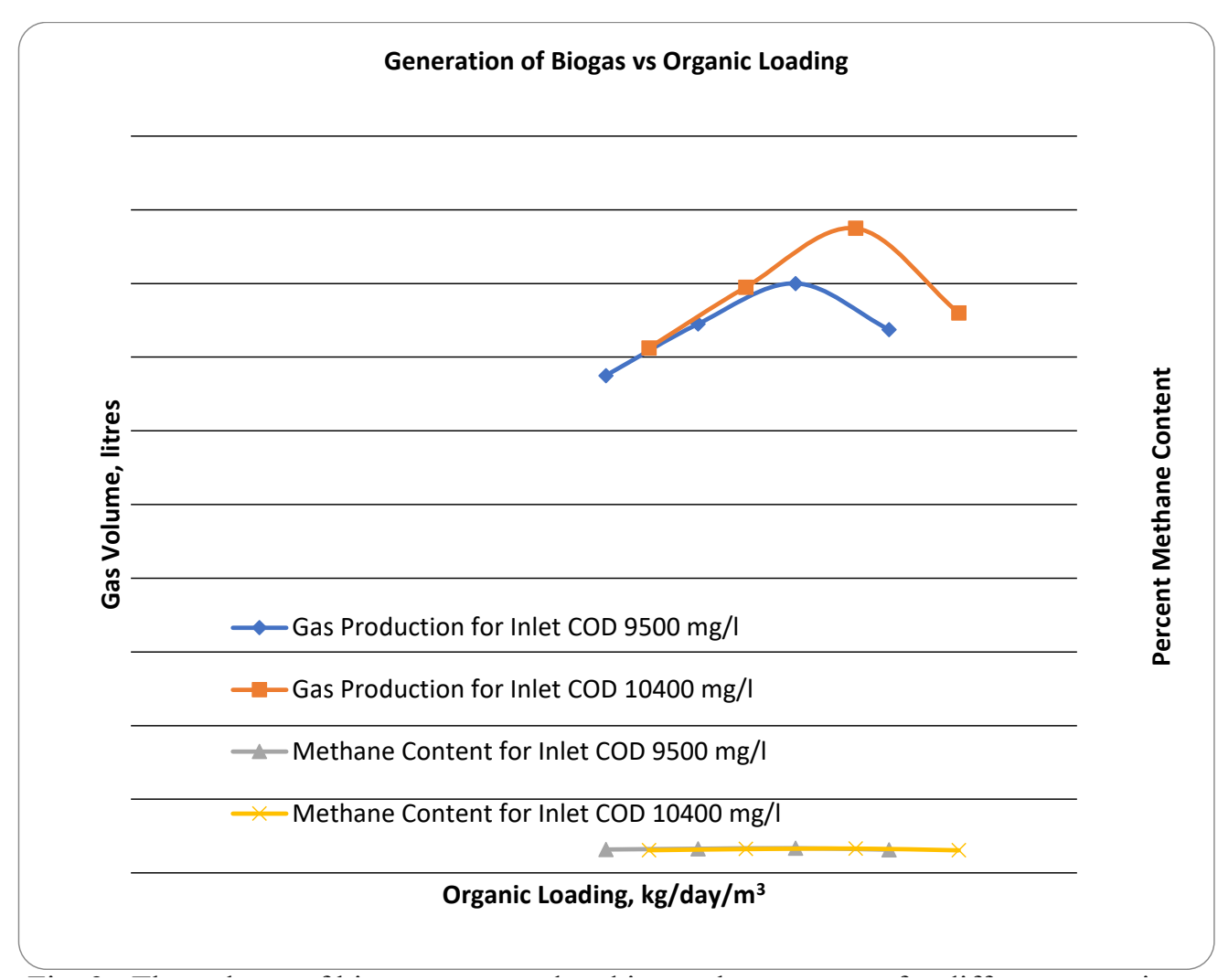

Fig. 9: The volume of biogas generated and its methane content for different organic loadings.

duction, the methane content of the gas increased from 63 percent to 67 percent on changing the organic loading rate from $6.0 \mathrm{~kg}$.day. $\mathrm{m}^{-3}$ to $8.4 \mathrm{~kg}$.day. $\mathrm{m}^{-3}$ for an influent COD concentration of $9500 \mathrm{mg} \cdot \mathrm{L}^{-1}$. The methane content of the biogas was found to decrease to 62 percent on increasing the organic loading rate to $9.6 \mathrm{~kg}$.day. $\mathrm{m}^{-3}$. The same trend was observed for the influent concentration of 10400 mg. $\mathrm{L}^{-1}$.

The drop in gas production and methane content beyond a particular organic loading rate could be attributed to the lesser organic removal at higher organic loadings and lesser activation of methanogenic bacteria (Mata-Alvarez et al. 2000). The specific biogas yield expressed as lit $\mathrm{CH}_{4} \cdot \mathrm{gm}^{-1}$ COD destroyed/day for the various organic loadings studied is given in Table 3.

\section{CONCLUSIONS}

1. The upflow anaerobic filter successfully treated the wastewater from a centrifuge rubber latex concentration unit at influent COD concentrations as high as 10400 mg. $\mathrm{L}^{-1}$. The maximum COD removal and BOD removal recorded after 15 days of continuous steadystate operation of the filter was 91 percent and 95 percent respectively at an organic loading rate of 8.4 $\mathrm{kg}$.COD.day. $\mathrm{m}^{-3}$ and a hydraulic retention time of 1.2 days.

2. The COD and BOD removal efficiency of the filter was found to increase on increasing organic loading up to a certain limit. On increasing the organic loading further, the removal efficiency was found to drop.

3. The maximum volume of biogas production recorded during the period of investigation was 117 L.day $^{-1}$. The percentage methane content of the gas ranged from 61 to 67 percent.

4. A pH range of 6.4 to 7.3 was observed during the study. Even though a reduction in $\mathrm{pH}$ was observed initially, it remained almost neutral subsequently.

5. For all the organic loading rates, there was a steep increase in the volatile acids concentration during the initial period, but subsequently, it came down. 
Table 3: The specific biogas yield for various organic loadings.

\begin{tabular}{|c|c|c|}
\hline Influent COD Concentration [mg. $\left.\mathrm{L}^{-1}\right]$ & Organic Loading Rate $\left[\mathrm{kg}\right.$.day. $\left.\mathrm{m}^{-3}\right]$ & Specific Methane Production $\mathrm{L} \mathrm{CH}_{4} \cdot \mathrm{g}^{-1} \mathrm{COD}$ destroyed/day \\
\hline \multirow[t]{4}{*}{9500} & 6.0 & 13.97 \\
\hline & 7.2 & 13.07 \\
\hline & 8.4 & 12.16 \\
\hline & 9.6 & 9.49 \\
\hline \multirow[t]{4}{*}{10400} & 6.57 & 13.25 \\
\hline & 7.88 & 12.71 \\
\hline & 9.19 & 12.21 \\
\hline & 10.50 & 8.98 \\
\hline \multirow[t]{4}{*}{5800} & 3.66 & 13.53 \\
\hline & 4.39 & 12.79 \\
\hline & 5.13 & 11.97 \\
\hline & 5.86 & 8.31 \\
\hline \multirow[t]{4}{*}{4620} & 2.92 & 13.48 \\
\hline & 3.50 & 12.57 \\
\hline & 4.08 & 10.89 \\
\hline & 4.67 & 8.22 \\
\hline
\end{tabular}

\section{REFERENCES}

Acharya, B.K, Mohana, S. and Madamwar, D. 2008. Anaerobic treatment of distillery spent wash- A study on upflow anaerobic fixed-film bioreactor, Bioresour. Technol., 99: 4621-4626.

APHA, AWWA and WPCF. 1995. Standard Methods for the Examination of Water and Wastewater. American Public Health Association, Inc, Washington D.C.

Behera, S.K., Rene, E.R. and Murthy, D.V.S. 2007. Performance of upflow anoxic bioreactor for wastewater treatment. Int. J. Environ. Sci. Tech., 4(2): 247-252.

Bodik, I., Herdova, B. and Drtil, M. 2002. The use of upflow anaerobic filter and AnSBR for wastewater treatment at ambient temperature. Water Res., 36(4): 1084-1088.

Bodik, I., Kratochvil, K., Gasparikova, E. and Hutnan, M. 2003. Nitrogen removal in an anaerobic baffled filter reactor with aerobic post-treatment. Bioresour. Technol., 86: 79-84.

Burcu, A.C., Cansu, F.I. and Semra, I. 2016. The anaerobic treatment of pharmaceutical industry wastewater in an anaerobic batch and upflow packed-bed reactor. Desal. Water Treat., 57(14): 54-69.

Delpozo, R., Diez, V. and Beltran, S. 2000. Anaerobic pretreatment of slaughterhouse wastewater using fixed-film reactors. Bioresour. Technol., 71(2): 143-149.

Hanne, V.H. and Birgitte, K.A. 1996. Integrated removal of nitrate and carbon in an upflow anaerobic sludge blanket (UASB) reactor: Operating performance. Water Res., 30(6): 1451-1458.

Iscen, C.F., Ilhan, S. and Yildirim, M.E. 2007. Treatment of cake production wastewater in upflow anaerobic packed bed reactor. Int. J. Nat. Eng. Sci., 1: 75-80.

Kobayashi, H.A., Stenstrom, M.K. and Mah R.A. 1983. Treatment of low strength domestic wastewater using the anaerobic filter, Water Res., 17(8): 903-909.
Ioannis, D., Manariotis, I. and Sotirios, G.G. 2006. Municipal-wastewater treatment using upflow-anaerobic filters. Water Environ. Res., 78(3): 233-242.

Madhu, G., George, K.E. and Joseph Francis, D. 1994. Treatment of natural rubber latex concentration wastewaters by stabilization pond. Int. J. Environ. Studies, 46: 69-74.

Manariotis, I.D. and Grigoropoulis S.G. 2006. Anaerobic filter treatment of municipal wastewater: biosolids behavior J. Environ. Eng., 132: 23-31.

Mata-Alvarez, J., Mace, S. and Llabres, P. 2000. Anaerobic digestion of organic solid wastes. An overview of research achievements and perspectives. Bioresour Technol., 74(1): 3-16.

Omil, F., Garrido, J.M., Arrojo, B. and Mendez, R. 2003. Anaerobic filter reactor performance for the treatment of complex dairy wastewater at an industrial scale. Water Res., 37(17): 4099-108.

Rajakumar, R., Meenambal, T., Rajesh Banu, J. and Yeom I.T. 2011. Treatment of poultry slaughterhouse wastewater in upflow anaerobic filter under low upflow velocity. Int. J. Environ. Sci. Tech., 8(1): 149-158.

Sharma, M.K., Khursheed A. and Kazmi, A.A. 2014. Modified septic tank-anaerobic filter unit as a two-stage onsite domestic wastewater treatment system. Environ. Technol., 35: 2183-2193.

Tilche, A., Bortone, G., Forner, G. and Indulti M. 1994. Combination of anaerobic digestion and denitrification in a hybrid upflow anaerobic filter integrated into a nutrient removal treatment plant. Art. Water Sci. Technol., 30(12): 405-414.

Tritt WP. 1992. The anaerobic treatment of slaughterhouse wastewater in fixed-bed reactors. Bioresour. Technol., 41(3): 201-7.

Young, J.C. and Mc Carty, P.L. 1969. The anaerobic filter for waste treatment. J. Wat. Pollut. Control Fed., 41(5): 160-173.

Zabihollah, Y., Mohammad, B. and Reza, A.M. 2018. Slaughterhouse wastewater treatment by combined anaerobic baffled reactor and anaerobic filter: Study of OLR and HRT optimization in ABR/AF reactors. Environ. Health Eng. Manag. J., 5(3): 137-142. 